NDP Kinase 유전자를 과발현시킨 형질전환 톨 페스큐 식물체의

$$
\text { 저온 스트레스에 대한 내성 특성 }
$$

이상훈*** • 이기원*,** · 김경희* · 윤대진* . 곽상수*** • 이병현*

\title{
Characterization of Transgenic Tall Fescue Plants Overexpressing NDP Kinase Gene in Response to Cold Stress
}

\author{
Sang-Hoon Lee*,**, Ki-Won Lee*,**, Kyung Hee Kim*, Dae-Jin Yun*, Sang-Soo Kwak*** \\ and Byung-Hyun Lee*
}

\begin{abstract}
Oxidative stress is the main limiting factor in crop productivity. To solve global environmental problems using the plant biotechnology, we have developed on the oxidative stress-tolerant transgenic tall fescue plants via Agrobacterium-mediated genetic transformation method. In order to develop transgenic tall fescue (Festuca arundinacea Schreb.) plants with enhanced tolerance to multiple environmental stresses, nucleotide diphosphate kinase gene under the control of CaMV35S promoter were introduced into genome of tall fescue plants. Proteomic analysis revealed that transgenic tall fescue not only accumulated NDP kinase 2 protein in their cells, but also induced several other antioxindative enzyme-related proteins. When leaf discs of transgenic plants were subjected to cold stress, they showed approximately $30 \%$ less damage than wild-type plants. In addition, transgenic tall fescue plants showed normal growth when transgenic plants were subjected to $4^{\circ} \mathrm{C}$ for 3 days treatments. These results suggest that transgene is important in ROS scavenging by induction of antioxidative proteins, and could improve abiotic stress tolerance in transgenic tall fescue plants.
\end{abstract}

(Key words : Tall fescue, Antioxidant gene, Agrobacterium, Transformation)

$$
\text { I. 서 론 }
$$

고등식물에 있어서 활성산소 (reactive oxygen species, ROS)인 superoxide radical $(\cdot \mathrm{O} 2)$, hydrogen peroxide $\left(\mathrm{H}_{2} \mathrm{O}_{2}\right)$, hydroxyl radical $(\cdot \mathrm{OH})$ 등은 건 조, 고온, 저온, 염 및 중금속 등의 물리-화학 적인 비생물학적 스트레스와 생물적 스트레스
에 의해서도 생성된다(Foyer 등, 1994; Allen 등, 1997; Asada, 1999). 이와 같은 ROS는 강한 산화력을 가지고 있어서 세포막의 파괴, 단백 질 분해, DNA 합성 억제, 광합성 억제, 엽록체 파괴 등 식물체 내에서 심각한 생리적인 장해 를 주며 많은 양의 ROS가 과도하게 축적되면 세포가 고사하게 된다. 식물은 이와 같은 ROS

* 경상대학교 응용생명과학부, 농업생명과학연구원 (Division of Applied Life Science(BK21), Institute of Agriculture and Life Science, Gyeongsang National University)

** 농촌진흥청 국립축산과학원 (National Livestock Research Institute, RDA)

*** 한국생명공학연구원 (Korea Research Institute of Bioscience and Biotechnology (KRIBB), Daejeon 305-806)

Corresponding author: Byung-Hyun Lee, Division of Applied Life Science (BK21), Gyeongsang National University, Jinju 660-701, Korea Tel: +82-55-751-5418, Fax: +82-55-751-5410, E-mail: hyun@gnu.ac.kr 
를 생성시키는 다양한 환경 스트레스에 대해 방어하기 위해 superoxide dismutase (SOD), peroxidase (POD), catalase (CAT) 등과 같은 항 산화효소계를 가지고 있을 뿐만 아니라, ascorbate (vitamin $\mathrm{C}$, ascorbic acid), 비타민 E (tocopherol), glutathione 등과 같은 저분자 항산 화물질들을 생합성함으로써 식물체내에서 활성 산소를 효과적으로 제거시키는 시스템이 잘 발 달되어 있다(Foyer 등, 1994; Noctor와 Foyer, 1998). 그러나 이러한 방어체계도 과도한 스트 레스가 지나치게 계속되면 식물체는 적응하지 못하고 생육이 정지됨으로써, 작물의 경우 수 량감소와 직결된다. 지금까지 이와 같은 환경 스트레스 하에서도 내성을 가지는 작물을 개발 하기 위해서 항산화효소 유전자와 같은 다양한 down stream 유전자들을 형질전환기술로 도입 하여 내성이 증가되는 결과를 가져 온 예가 많 이 보고되어 왔다. 그러나 이와 같은 방법은 여러 가지의 스트레스에 동시에 노출되는 경우 의 복합적인 스트레스에 내성을 가진 작물을 개발하기 위해서는 다수의 유전자를 반복적으 로 도입해야 하는 번거로움이 있다. 애기장대 의 NDP kinase 2 유전자는 산화스트레스 신호 전달경로의 upstream에서 항산화기구를 효율적 으로 제어함으로써 복합적인 스트레스에 대해 내성을 가지도록 하는 유전자로 알려져 있다 (Moon et al. 2003). 따라서 이 유전자를 목초 에 도입하여 성공적으로 발현시킬 수 있다면 목초의 생산성 향상에 크게 기여할 수 있을 것 이다.

최근 목초 또는 사료작물에 유용유전자의 도 입에 의한 신품종 개발 연구가 많이 시도되고 있으며, 특히, 환경 스트레스에 대한 내성을 향 상시키기 위한 사료작물의 형질전환 식물체 개 발에 관한 많은 연구가 보고되고 있다 (Spangenberg 등, 1998; Lee 등, 2004; Dang과 $\mathrm{Qu}, 2005$; Wang과 $\mathrm{Ge}, 2005$; Lee 등 2006). 톨 페스큐는 다년생 화본과 목초로서 공원, 골프 장 등에 있어서 토양보존용 잔디로도 많이 개
발되어 이용되고 있다(Buckner 등, 1979). 본 연구에서는 Agrobacterium 을 이용한 형질전환 법으로 항상적인 발현 promoter인 CaMV35S 하 류에 애기장대 NDP kanase 2 유전자가 발현되 도록 구축한 벡터를 톨 페스큐에 형질전환하여 여러 가지 환경 스트레스 중, 우선 저온 스트 레스에 대한 내성특성을 조사하였다.

\section{ㅍ. 재료 및 방법}

\section{1. 종자소독 및 캘러스 배양}

형질전환을 위한 식물재료로는 톨 페스큐의 Kentucky-31 품종을 사용하였다. 종자살균은 성 숙종자의 종피를 제거한 다음 $70 \%$ ethanol에서 30 초간 살균한 후, $30 \%$ sodium hypochlorite 용 액에서 30 분간 교반하면서 표면살균 하였다. 살균한 종자는 멸균수로 3 회 세정한 후, 멸균 된 filter paper에 옮겨 물기를 제거하고 $\mathrm{MS}$ 배 지 (Murashige와 Skoog, 1962)를 기본으로 하는 캘러스 유도배지 (Lee 등, 2004)에 치상한 후 암상태에서 6주간 배양하여 캘러스를 유도하였 다. 유도된 캘러스를 $5 \mathrm{~mm}$ 크기로 절단하여 새 로운 캘러스 유도배지에서 암상태로 3주간 계 대배양하여 캘러스를 증식시킨 후 Agrobacterium 감염을 이용한 형질전환에 이용하였 다.

\section{Agrobacterium 배양 및 발현벡터}

형질전환을 위한 발현벡터는 CaMV35S promoter 하류에 애기장대 NDP kinase 2 유전 자를 도입하여 항상적으로 발현될 수 있도록 연결한 후, hygromycin phosphotransferase (HPT) 를 선발 표지로 가지고 있는 pCAMBIA1300 발현벡터에 도입하여 사용하였다. 발현벡터를 Agrobacterium strain EHA105에 형질전환한 후, 단일 colony를 선발하여 kanamycin $(\mathrm{Km})$ 과 hygromycin $(\mathrm{Hm})$ 이 각각 $50 \mathrm{mg} / \mathrm{L}$ 로 첨가된 
YEP 액체배지에 접종, 배양하여 캘러스의 감 염에 이용하였다. Agrobacterium의 감염과 공동 배양은 Lee 등 (2004)의 방법에 준하여 실시하 였다.

\section{3. 톨 페스큐 형질전환 및 식물체 재분화}

성숙종자 유래의 캘러스를 이용한 형질전환 은 Lee 등 (2004)의 방법에 준하여 실시하였다. 성숙종자로부터 유도된 $3 \sim 5 \mathrm{~mm}$ 크기의 캘러스 를 Agrobacterium을 현탁시킨 접종배지에 1시 간 침지시켜 감염시킨 다음, 여분의 Agrobacterium 을 멸균된 filter paper 위에서 제거하였다. 감염시킨 캘러스를 공동배양배지 (MS medium, $3 \mathrm{mg} / \mathrm{L}$ 2,4-dichlorophenoxyacetic acid (2,4-D), $200 \mu \mathrm{M}$ acetosyringone (AS), $500 \mathrm{mg} / \mathrm{L}$ L-proline, $30 \mathrm{~g} / \mathrm{L}$ sucrose, $3 \mathrm{~g} / \mathrm{L}$ Gelite)에 계대한 후 $26^{\circ} \mathrm{C}$ 에서 5일간 암상태로 공동배양 하였다. 공동배 양한 캘러스는 $500 \mathrm{mg} / \mathrm{L}$ cefotaxime이 첨가된 공동배양배지로 세정하여 Agrobacterium 을 제 균한 후, post-culture배지 (MS medium, 500 $\mathrm{mg} / \mathrm{L}$ cefotaxime, $3 \mathrm{mg} / \mathrm{L} \quad 2,4-\mathrm{D}, \quad 1 \mathrm{mg} / \mathrm{L} \quad 6-$ benzyladenine (BA), $1 \mathrm{~g} / \mathrm{L}$ casein hydrolysate, $500 \mathrm{mg} / \mathrm{L}$ L-proline, $3 \mathrm{mg} / \mathrm{L}$ thiamine- $\mathrm{HCl}, 30$ $\mathrm{g} / \mathrm{L}$ sucrose, $3 \mathrm{~g} / \mathrm{L}$ Gelrite)에 7일간 배양하였다.

공동배양과 post-culture를 실시한 캘러스는 선발배지 (N6 medium, $250 \mathrm{mg} / \mathrm{L}$ cefotaxime, 25 $\mathrm{mg} / \mathrm{L}$ hygromycin, $1 \mathrm{mg} / \mathrm{L}$ 2,4-D, $3 \mathrm{mg} / \mathrm{L}$ BA, 1 $\mathrm{g} / \mathrm{L}$ casein hydrolysate, $500 \mathrm{mg} / \mathrm{L}$ L-proline, 3 $\mathrm{mg} / \mathrm{L}$ thiamine- $\mathrm{HCl}, \quad 30 \mathrm{~g} / \mathrm{L}$ sucrose, $3 \mathrm{~g} / \mathrm{L}$ Gelrite)에서 3주간 배양하여 $\mathrm{Hm}$ 내성을 나타 내는 캘러스만을 선발하여 다시 $50 \mathrm{mg} / \mathrm{L} \mathrm{Hm}$ 이 첨가된 선발배지에 옮겨 4주간 배양하여 살아 남은 캘러스로부터 식물체를 재분화시켰다. 재 분화된 식물체는 $1 / 2 \mathrm{MS}$ 배지에 $50 \mathrm{mg} / \mathrm{L} \mathrm{Hm}$ 이 첨가된 배양병에 옮겨준 후, 4주간 배양하여 정상적으로 뿌리가 발육되고 살아남는 개체만 을 선발하여 pot로 이식하여 온실에서 재배하 였다.

\section{4. 도입 유전자의 확인}

식물생장상과 온실에서 재배한 형질전환 식 물체로부터 genomic DNA를 CTAB법 (Murray와 Thompson, 1980)에 준하여 분리한 후, Lee 등 (2006)의 방법에 준하여 genomic DNA $20 \mu \mathrm{g}$ 을 HindIII로 절단하여 $0.8 \%$ agarose gel로 전기 영동한 후 Southern blot 분석을 실시하였다. Southern blot 분석을 위한 probe DNA는 Lee 등 (2006)의 방법에 준하여 PCR로 증폭시킨 NDP kinase 2 유전자를 agarose gel 전기영동으 로 정제하여 사용하였다.

\section{5. 형질전환체의 프로테옴 분석 및 저온 스 트레스 내성 검증}

형질전환 식물체의 저온 스트레스에 대한 내 성 검증을 위하여 온실에서 6주간 배양한 형질 전환 식물체로부터 잎 절편을 조제하여 $4{ }^{\circ} \mathrm{C}$ 용 액에 띄워 광조건에서 24,48 및 72 시간 동안 배양한 다음 세포의 손상정도를 ion leakage로 측정하여 비교 하였다. 전식물체 (whole plant) 수준에서의 저온 스트레스 내성은 온실에서 6 주 동안 생육시킨 비형질전환 식물체와 형질전 환 식물체를 $4^{\circ} \mathrm{C}$ 식물생장상에 넣은 후, 광조 건에서 3 일간 배양한 다음 식물체의 손상정도 를 조사하여 비교하였다. 형질전환체의 프로테 옴분석을 위해 whole plant를 $4^{\circ} \mathrm{C}$ 식물생장상 광조건에서 24시간 동안 처리한 다음 톨 페스 큐의 잎으로부터 total protein을 추출한 다음, Ahsan 등 (2008)의 방법에 준하여 이차원전기영 동과 차별적 발현을 보인 단백질들의 동정을 실시하였다.

\section{III. 결과 및 고찰}

톨페스큐 형질전환체의 선발 및 유전자 확인 톨 페스큐 성숙종자로부터 유래된 캘러스를 Agrobacterium 으로 감염시켜 $50 \mathrm{mg} / \mathrm{L}$ 의 $\mathrm{Hm}$ 이 
첨가된 선발배지에서 선발한 후, 재분화된 형 질전환 식물체를 pot로 이식하여 온실에서 6주 간 재배하였다. 발현벡터에 포함되어있는 $\mathrm{T}$ DNA 영역이 형질전환 식물체의 genome내에 안정적으로 도입되었는지를 확인하기 위하여 형질전환 식물체의 잎으로부터 genomic DNA 를 추출한 후 NDP kinase 2 유전자를 probe로 사용하여 Southern blot 분석을 실시한 결과, 비 형질전환 식물체에서는 probe와 결합하는 DNA 단편을 확인할 수 없었으나, 형질전환식물체에 서는 DNA 단편이 관찰되어 transgene이 안정적 으로 도입되었음을 확인할 수 있었다(Fig. 1).

\section{2. 도입유전의 발현확인 및 프로테옴 분석}

형질전환체에 도입한 유전자가 정상적으로 과발현되고 있는지 여부와 이 NDP kinase 2 유전자의 과발현으로 인한 세포내 다른 유전자 들의 발현양상의 변화여부를 조사하기 위하여 형질전환체와 비형질전환체를 저온처리한 후, 각각의 잎 조직으로 부터 total protein을 추출

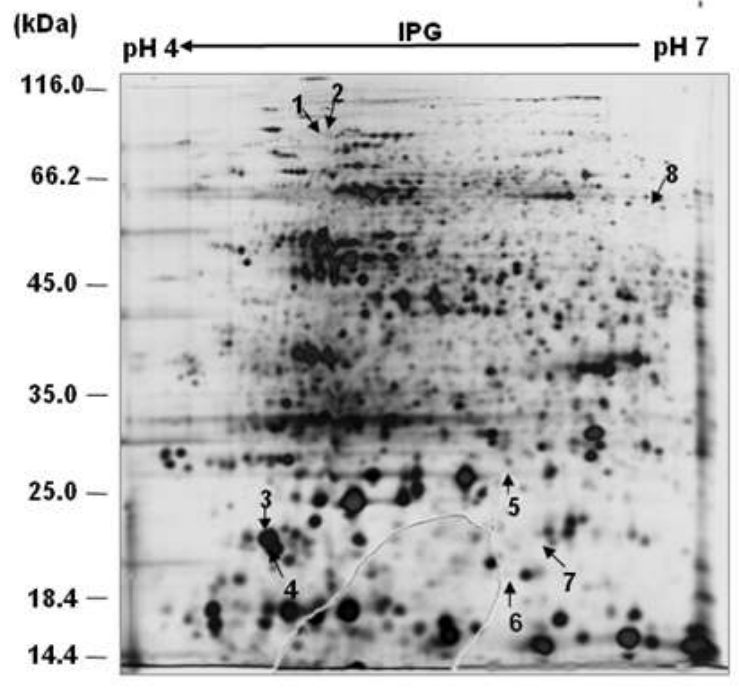

Control

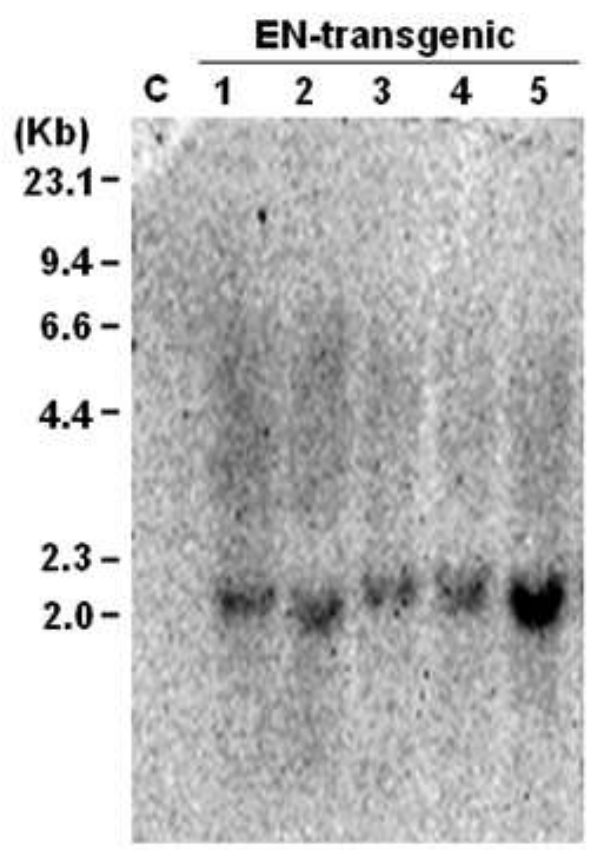

Fig. 1. Southern analysis of transgenic tall fescue plants. Genomic DNA of transgenic (1-5) and wild-type control plants (c), were digested with HindIII and hybridized with NDP kinase 2 probes.

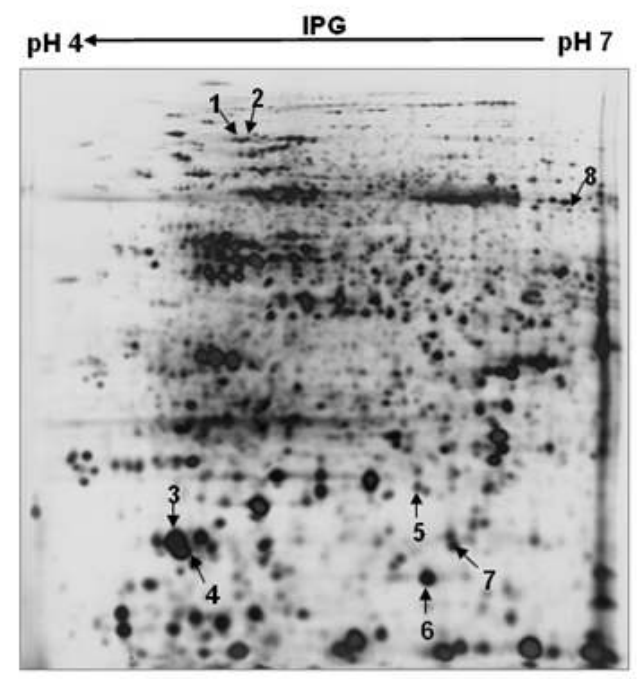

EN-transgenic

Fig. 2. Two-dimensional electrophoresis analysis of wild-type and transgenic tall fescue plant (EN) exposed to $4^{\circ} \mathrm{C}$. A total of $180 \mu \mathrm{g}$ proteins were extracted and separated by 2-DE, as described in Materials and methods, and visualized with silver staining. Arrows are indicating the identified and differentially expressed proteins in response to cold stress. 
한 후 이차원전기영동하여 silver 염색을 실시 하여 발현양상을 비교하였다(Fig. 2). 그 결과 다수의 단백질들이 차별적 발현을 나타내었으 며, 이들 중 대표적인 spot 8 개를 젤에서 분리 하여 MALDI-TOF 분석기로 질량을 분석한 후 protein database를 이용하여 단백질들을 동정하 였다 (Fig. 3).

그 결과 형질전환 식물체로 추출한 단백질 spot 5 가 NDP kinase 2로 동정되었다. 이러한 결과는 형질전환체에 도입된 transgene이 정상 적으로 과발현되고 있음을 나타낸다. 또한 비 형질전환체와 차별적 발현을 보였던 대표적인 단백질 spot들을 동정해 본 결과 HSP70 (spots 1,2 ), GSTs (spot 3, 4, 6, 7) 등과 같이 항산 화 관련 단백질들이 동정되었으며, serine/ threonine protein kinase와 같은 신호전달 관련
단백질들도 동정되었다. 이러한 결과는 항상적 으로 과발현 된 NDP kinase 2가 하위의 항산 화관련 유전자들의 발현을 유도함으로써 비롯 된 결과로 추측된다 (Moon 등, 2003).

\section{3. 형질전환체의 저온 내성 특성 조사}

한편 이러한 항산화관련 유전자들의 발현유 도가 실제로 재해내성 여부와 관련이 있는지 여부를 조사하기 위하여 우선 비형질전환 식물 체와 형질전환 식물체의 잎으로부터 잎 절편을 조제한 후 $4{ }^{\circ} \mathrm{C}$ 에서 72 시간 까지 시간별로 처리 한 후 용액내의 전기전도도를 측정하여 비교하 였다 (Fig. 4). 그 결과 wild-type 식물체의 경우 저온 스트레스 처리에 따라 세포의 손상으로 인한 ion leakage의 증가가 시간경과에 따라 급

A

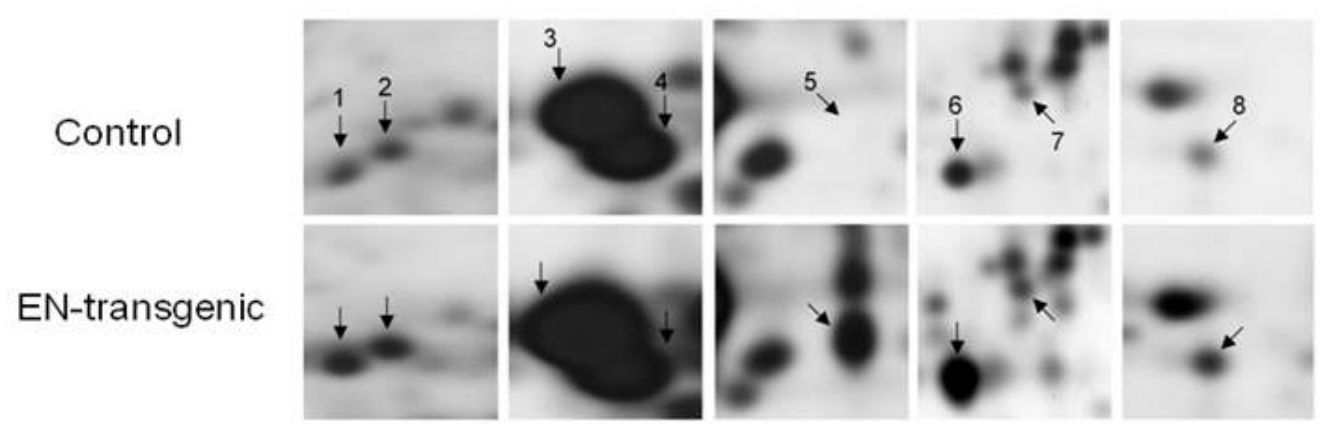

B

\begin{tabular}{cclcc}
\hline $\begin{array}{c}\text { Spot } \\
\text { No. }\end{array}$ & $\begin{array}{c}\text { SC } \\
(\%)\end{array}$ & \multicolumn{1}{c}{ Protein name } & Species & Acc. No. \\
\hline $\mathbf{1}$ & 19 & Heat shock 70 kD protein & G. max & 18663 \\
\hline $\mathbf{2}$ & 12 & Heat shock protein 70 & M. sativa & 56554972 \\
\hline $\mathbf{3}$ & 16 & AtGSTF12 (glutathione S-transferase 26) & A. thaliana & 15237931 \\
\hline $\mathbf{4}$ & 19 & AtGSTF12 (glutathione S-transferase 26) & A. thaliana & 15237931 \\
\hline $\mathbf{5}$ & 20 & Nucleoside diphosphate kinase type 2 & A. thaliana & 3093480 \\
\hline $\mathbf{6}$ & 17 & Putative glutathione S-transferase & O. sativa & 37536312 \\
\hline 7 & 17 & Putative glutathione S-transferase & O. sativa & 37536312 \\
\hline $\mathbf{8}$ & 20 & Serine/threonine protein kinase & O. sativa & 28864539 \\
\hline
\end{tabular}

Fig. 3. Identification of differentially expressed protein spots by cold stress. Close up view of differentially expressed proteins 【A】 and identification of each protein spot 【B】. Sc, sequence coverage; Acc. No.: accession number. 


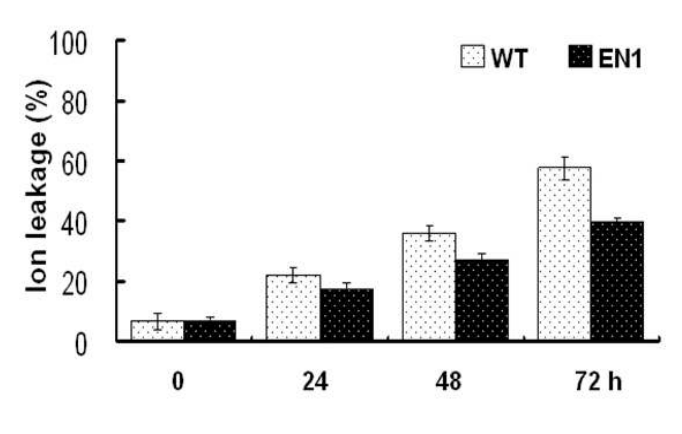

Treatment at $4^{\circ} \mathrm{C}$

Fig. 4. Effect of cold stress on ion leakage of wild-type control (WT) and transgenic(EN1) tall fescue plant for 3 days after treatment with $4{ }^{\circ} \mathrm{C}$.

격하게 증가한 반면, 형질전환 식물체의 경우 에는 비형질전환 식물체에 비해 약 $20 \%$ 이상 씩 더 낮은 ion leakage를 나타내었다. 이러한 결과는 형질전환체의 경우 도입유전자의 발현 에 의해 산화스트레스 중의 하나인 저온 스트 레스에 대한 내성이 증가되었음을 나타낸 결과 이다.

전식물체 (whole plant) 수준에서 저온 스트레 스 처리에 의한 내성 정도를 조사하기 위해 온 실에서 6 주 동안 생육시킨 wild-type 식물체와 형질전환 식물체를 $4^{\circ} \mathrm{C}$ 에서 3 일간 처리한 후 식물체의 손상 정도를 비교해 보았다. 그 결과 Fig. 5에 나타낸 바와 같이 wild-type 식물체는 잎 조직의 일부분이 고사되어 완전히 쓰러진 반면, 형질전환 식물체는 거의 손상을 받지 않 고 정상적인 생육을 지속하였다 (Fig. 5).

이러한 결과는 형질전환체에 도입한 $\mathrm{NDP}$ kinase 2 유전자가 정상적으로 발현되었고 또 이유전자의 조절을 받는 다수의 항산화 관련 유전자들의 발현이 유도됨으로써 저온 스트레 스 하에서의 세포손상을 방지한 결과로 추측된 다. 이와 유사한 결과가 형질전환 감자를 이용 한 Kim 등 (2009)의 연구에서도 보고된 바 있 다. 감자의 경우 superoxide dismutase (SOD)와 ascorbate peroxidase (APX)의 활성의 증가가 관

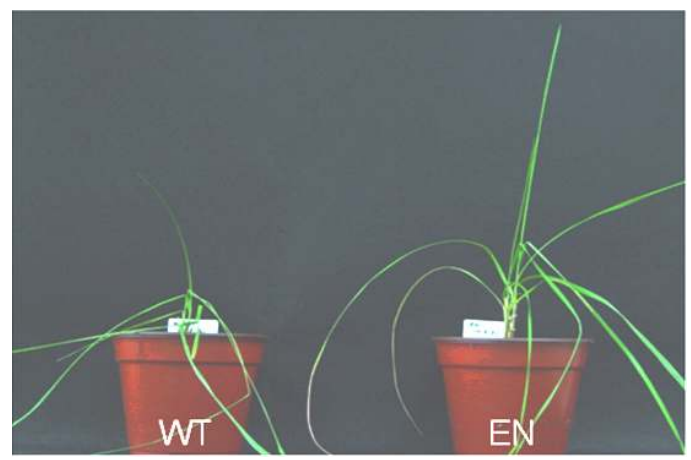

Fig. 5. Differential visible damages in the seedlings of wild-type (WT) and transgenic (EN) tall fescue plants at 3 days after treatment with cold stress $\left(4^{\circ} \mathrm{C}\right)$.

찰되었다고 보고한 바 있다 (Kim 등, 2009). 본 연구에서는 $\mathrm{SOD}$ 와 $\mathrm{APX}$ 단백질은 동정되지 않 았으나, 추후 더 많은 단백질 spot 들을 동정하 면 이들 단백질들의 차별적 발현도 발견 될 것 이다.

본 실험을 통하여 쌍자엽식물 유래의 $\mathrm{NDP}$ kinase 2 유전자가 단자엽식물인 톨 페스큐에서 도 정상적으로 발현 기능하고 있음을 학인 할 수 있었으며, 추후 다양한 환경 스트레스에 대 한 연구가 병행되면 복합적인 스트레스에 대한 내성 획득여부를 확인할 수 있을 것이며, 복합 재해내성 목초를 개발하는 소재로도 활용 할 수 있을 것이다.

\section{IV. 요 약}

저온 스트레스에 대한 내성을 지닌 신품종 톨 페스큐를 개발할 목적으로 CaMV35S 프로 모터 하류에 NDP kinase 2 유전자가 항상적으 로 발현하도록 제작한 벡터를 Agrobacterium 법 을 이용하여 톨 페스큐에 도입하였다. Hygromycin 이 첨가된 선발배지에서 내성을 나타내며 재분 화된 형질전환 식물체를 pot로 이식하여 기내 순화 시킨 후, Southern blot 분석을 실시하여 본 결과, NDP kinase 2 유전자가 형질전환 식 
물체의 genome에 정상적으로 도입되었음을 확 인하였다. 프로테옴 분석을 통하여 도입유전자 의 조절을 받는 항산화관련 유전자들의 발현이 유도되었음을 확인 할 수 있었다. 형질전환 식 물체 잎 절편을 산화스트레스 중의 하나인 저 온 스트레스를 처리하여 세포의 손상 정도를 조사한 결과, 비형질전환체에 비해 형질전환체 는 강한 내성을 나타내었다. 또한 유식물체 수 준에서 저온 스트레스를 처리하여 내성을 비교 한 결과, 비형질전환체에 비해 형질전환체는 높은 내성을 나타내었다. 이 형질전환 톨페스 큐는 산화스트레스 내성 품종개발을 위한 소재 로 활용 될 수 있을 것이다.

$$
\text { V. 사 사 }
$$

본 연구는 농촌진흥청 바이오그린21사업의 연구비지원 (과제번호: 20070301034015)에 의해 이루어진 것이며, 이에 감사드립니다.

\section{VI. 인 용 문 헌}

1. Ahsan, N., D.-G. Lee, I Alam, P.J. Kim, J.J Lee, Y.-O. Ahn, S.-S. Kwak, I.-J. Lee, J.D. Bahk, K.Y. Kang, J Renaut, S Komatsu and B-H Lee. 2008. Comparative proteomic study of arsenic-induced differentially expressed proteins in rice roots reveals glutathione plays a central role during As stres. Proteomics 8: 3561 - 3576.

2. Allen, R.D., R.P. Webb and S.A. Schake. 1997. Use of transgenic plants to study antioxidant defenses. Free Radical Biol. Med. 23:473-479.

3. Asada, K. 1999. The water-water cycle in chloroplasts: scavenging of active oxygens and dissipation of excess photons. Annu. Rev. Plant Physiol. Plant Mol. Biol.. 50:601-639.

4. Buckner, R.C., J.B., Powell and R.V. Frakes. 1979. Historical development. In: Buckner RC, Bush LP(eds) Tall Fescue. Agronomy 20:1-8.

5. Dong, S. and R. Qu. 2005. High efficiency transformation of tall fescue with Agrobacterium tumefaciens. Plant Sci. 168:1453 - 1458.

6. Foyer, C.H., P. Descourvierse, and K.J. Kunert. 1994. Protection against oxygen radicals: an important defense mechanism studied in transgenic plants. Plant Cell Environ. 17:507-523.

7. Kim, Y.H., S. Lim, K.S. Yang, C.Y. Kim, D. S.Y. Kwon, H.S. Lee, X. Wang, Z. Zhou, Ma, D.J. Yun and S.S. Kwak. 2009. Expression of Arabidopsis NDPK2 increases antioxidant enzyme activities and enhances tolerance to multiple environmental stresses in transgenic sweetpotato plants. Mol Breeding 24:233-244.

8. Lee, S.-H., D.-G. Lee, H.-S. Woo, K.-W. Lee, D.-H. Kim, SS. Kwak, J.-S. Kim, H.G. Kim, N. Ahsan, MS. Choi, J.K. Yang and B.-H. Lee. 2006. Production of transgenic orchardgrass via Agrobacterium-mediated transformation of seedderived callus tissues. Plant Sci. 171:408-414.

9. Lee, S.-H., D.-G. Lee, H.-S Woo, B.-H. Lee. 2004. Development of transgenic tall fescue plants from mature seed-derive callus via Agrobacteriummediated transformation. Asian-Aust J Anim Sci. 17:1390 - 1394.

10. Moon, H., Lee, B., Choi, G., Shin, D., Prasad, D.T., Lee, O., Kwak, S.S., Kim, D.H., Nam, J., Bahk, J., Hong, J.C., Lee, S.Y., Cho, M.J., Lim, C.O. and Yun, D.J. 2003. NDP kinase 2 interacts with two oxidative stress-activated MAPKs to regulate cellular redox state and enhances multiple stress tolerance in transgenic plants. Proc. Natl. Acad. Sci. USA 100:358-363.

11. Murashige T. and F. Skoog. 1962. A revise medium for rapid growth and bioassays with tobacco tissue cultures. Physiol Plant 15:473-497.

12. Murray, M.G. and P.F. Tompson. 1980. Rapid isolation of high molecular weight plant DNA. Nucleic Acid Res. 8:4321-4325.

13. Noctor, G. and C.H. Foyer. 1998. Ascorbate and glutathine: keeping active oxygen under control. 
Lee et al.: Transgenic Tall Fescue Plant

Annu Rev Plant Physiol Plant Mol Biol. 49:249-279.

14. Spangenberg, G., Z.Y. Wang and I. Potrykus. 1998. Biotechnology in forage and turf grass improvement. In: Frankel et al (Eds), Monographs on theoretical and applied genetics, Vol. 23, Springer Verlag, Heidelberg, p. 192-211.
15. Wang, Z.-Y. and Y. Ge. 2005 Agrobacteriummediated high efficiency transformation of tall fescue (Festuca arundinacea Schreb.). J. Plant Physiol. 162:103-113.

(접수일: 2009년 10월 26일, 수정일 1차: 2009년 11 월 18일, 수정일 2차: 2009년 11월 24일, 게재확정일: 2009년 12월 7일) 